\title{
Pengaruh Penerapan Media Pembelajaran Pop-Up Book Terhadap Motivasi Dan Hasil Belajar IPA Peserta Didik Kelas V SDN 3 Kawo Tahun Ajaran 2020/2021
}

\author{
Sir'aini Salim Tuwijati ${ }^{1 *}$, H. Muhammad Liwa Ilhamdi ${ }^{2}$, Safruddin $^{3}$ \\ Program Studi Pendidikan Guru Sekolah Dasar FKIP Universitas Mataram \\ Email Coresspondent: siraini088@gmail.com ${ }^{1 *}$
}

\begin{abstract}
This study aims to determine the effect of the application of pop-up book learning media on the motivation and learning outcomes of fifth grade students at SDN 3 KAWO in the 2020/2021 academic year. The population in this study were all students of class V at SDN 3 KAWO, while the samples were students of class VA as the experimental class and students of class VB as the control class. Data analysis begins with a normality test using the One-Sample Kolmogrov Smirnov formula with a significance level of 5\% (0.05) and continues with a homogeneity test further testing the research hypothesis and further testing with a gain-score test. Then the motivational data and learning outcomes were analyzed by Independent $t$-test. Samples Test to determine the research hypothesis, the results of data analysis obtained a t-count value of 3,241 while the t-table at a significance level of 5\% was 2,048 so that the t-count value>t-table, which means that $\mathrm{H}_{\mathrm{a}}$, which states there is an effect of application pop-up book learning media on science learning motivation of fifth grade students at SDN 3 KAWO in the 2020/2021 academic year, was accepted and $\mathrm{H}_{0}$ rejected. And the obtained t-count is 2.209 while the t-table at the $5 \%$ significance level is 2.048 so that the $t$-count value is $>\mathrm{t}$-table, which means that $\mathrm{H}_{\mathrm{a}}$ which states that there is an effect of the application of pop-up book learning media on participants' science learning outcomes fifth grade students of SDN 3 KAWO for the academic year 2020/2021, were accepted and $\mathrm{H}_{0}$ was rejected. Then a follow-up test was carried out using gain-score test, the value of learning motivation is 0.403 which is included in the medium category, while the learning outcomes of 0.576 are included in the medium category.
\end{abstract}

Keywords: Pop-Up Book Learning Media, Learning Motivation and Learning Outcomes IPA

\begin{abstract}
Abstrak
Penelitian ini bertujuan untuk mengetahui pengaruh penerapan media pembelajaran pop-up book terhadap motivasi dan hasil belajar peserta didik kelas V SDN 3 KAWO tahun ajaran 2020/2021. Penelitian ini adalah penelitian kuantitatif dengan rancangan penelitian Non-equivalent control group design tipe quasi eksperimen. Populasi dalam penelitian adalah seluruh peserta didik kelas V SDN 3 KAWO, sedangkan sampel adalah peserta didik kelas VA sebagai kelas eksperimen dan peserta didik kelas VB sebagai kelas kontrol. Analisis data diawali dengan uji normalitas menggunakan rumus One-SampleKolmogrov smirnov dengan taraf signifikansi 5\% (0.05) dan dilanjutkan dengan uji homogentias selanjutnya menguji hipotesis penelitian dan uji lanjutan dengan uji gain-score. Kemudian data motivasi dan hasil belajar dianalisis dengan uji-t Independent Samples Test untuk mengetahui hipotesis penelitian, Hasil analisis data didapatkan nilai t-hitung sebesar 3.241 sedangkan t-tabel pada taraf signifikansi 5\% adalah sebesar 2.048 sehingga diperoleh nilai t-hitung > t-tabel, yang berarti bahwa Ha yang menyatakan ada pengaruh penerapan media pembelajaran pop-up book terhadap motivasi belajar IPA peserta didik kelas V SDN 3 KAWO tahun ajaran 2020/2021, diterima dan $\mathrm{H}_{0}$ ditolak. Dan diperoleh t-hitung sebesar 2.209 sedangkan t-tabel pada taraf signifikansi $5 \%$ adalah sebesar 2.048 sehingga diperoleh nilai t-hitung > t-tabel, yang berarti bahwa $\mathrm{H}_{\mathrm{a}}$ yang menyatakan ada pengaruh penerapan media pembelajaran pop-up book terhadap hasil belajar IPA peserta didik kelas V SDN 3 KAWO tahun ajaran 2020/2021, diterima dan $\mathrm{H}_{0}$ ditolak. Maka dilakukan uji lanjutan menggunakan uji gain-score maka di peroleh nilai motivasi belajar sebesar 0,403 termasuk dalam kategori sedang, sedangkan hasil belajar sebesar 0,576 termasuk dalam kategori sedang
\end{abstract}

Kata Kunci: Media Pembelajaran Pop-Up Book, Motivasi Belajar dan Hasil Belajar IPA

\section{PENDAHULUAN}

Menurut UU. No 20 tahun 2003 pendidikan adalah usaha sadar yang terencana untuk mewujudkan suasana belajar dan proses pembelajaran agar peserta didik secara aktif mengembangkan potensi dirinya untuk memiliki kekuatan spiritual keagamaan, pengendalian diri, kepribadian, kecedasan, akhlak mulia, serta keterampilan yang di perlukan dirinya, masyarakat, bangsa dan negara.

IPA merupakan mata pelajaran pokok dalam kurikulum pendidikan di Indonesia, termasuk pada jenjang pendidikan Sekolah Dasar. IPA atau yang sering disebut dengan Sains berupaya untuk meningkatkan minat 
manusia agar mau meningkatkan kecerdasan dan pemahamnnya tentang alam seisinya yang penuh dengan rahasia yang tidak ada habishabisnya. Susanto (2013:166), Ilmu Pengetahuan Alam adalah usaha manusia dalam memahami alam semesta melalui pengamatan yang tepat pada sasaran, serta menggunakan prosedur, dan dijelaskan dengan penalaran, sehingga mendapatkan suatu kesimpulan.

Dalam pembelajaran IPA, apabila proses pembelajaran dirancang dan dilaksanakan secara monoton dan tanpa adanya media dan model pembelajaran yang tepat dapat mengakibatkan peserta didik kurang termotivasi dalam memahami materi yang diajarkan oleh guru. Dengan adanya motivasi peserta didik untuk belajar, maka akan mempengaruhi hasil belajarnya. Motivasi merupakan pemberian rangsangan kepada motif agar muncul sehingga individu mau berbuat sesuai dengan tujuan yang diinginkan (Zuldafrial, 2012:96). Dari pengertian tersebut, dapat disimpulkan bahwa motivasi dapat berfungsi sebagai pendorong usaha, arah untuk belajar dan mendorong untuk pencapaian hasil belajar peserta didik. Dengan kata lain, semakin tinggi motivasi belajar yang dimiliki peserta didik, semakin tinggi pula kemungkinan untuk berhasil atau berprestasi. Jadi tugas guru yaitu mendorong dan membangkitkan semangat peserta didik agar dalam diri peserta didik tumbuh motivasi yang kuat untuk belajar.

Dengan menggunakan media dan metode pembelajaaran yang tepat, maka akan membantu pencapaian motivasi dan hasil belajar peserta didik yang optimal. Salah satu media pembalajaran yang sesuai untuk diterapkan adalah media pop-up book.

Adanya penggunaan media dapat mendukung proses pembelajaran, mempermudah peserta didik dalam memahami materi pembelajaran, serta meningkatkan kualitas mengajar guru yang akan berdampak pada hasil belajar siswa. Menurut Sylvia \& Hariani (2015) Pop-Up Book adalah sebuah buku cerita bergambar dengan gambar yang lucu atau yang bentuknya menarik, karena dapat bergerak ketika halamnnya dibuka.
Berdasarkan uraian diatas peneliti tertarik untuk melakukan penelitian yang berjudul "Pengaruh Penerapan Media Pembelajaran Pop-Up Book Terhadap Motivasi dan Hasil Belajar IPA Peserta Didik Kelas V SDN 3 KAWO Tahun Ajaran 2020/2021" perlu dilakukan.

\section{METODE PENELITIAN}

Penelitian ini merupakan penelitian eksperimen. Menurut Sugiyono (2019: 110) menjelaskan bahwa penelitian eksperimen merupakan penelitian yang digunakan untuk mencari pengaruh perlakuan tertentu terhadap yang lain dalam kondisi yang terkendalikan. Jenis penelitian yang digunakan yaitu Quasi experimental design yang mempunyai kelompok kontrol, tetapi tidak dapat berfungsi sepenuhnya untuk mengontrol variabelvariabel luar yang mempengaruhi pelaksanaan eksperimen. Tipe penelitian yang digunakan yaitu non equivalent control group design. Penelitian ini dilakukan terhadap dua kelas yakni kelas eksperimen dan kelas control

Sampel dalam penelitian ini adalah peserta didik kelas V SDN 3 KAWO dengan jumlah 30 peserta didik. Materi pelajaran pada penelitian ini adalah organ gerak hewan dan manusia. Penelitian ini dilaksanakan pada semester gasal tahun pelajaran 2021 yang bertempat di SDN 3 KAWO. Penelitian ini dilakukan terhadap dua kelas yakni kelas eksperimen dan kelas kontrol. Kelas eksperimen diberi perlakuan dengan menggunakan media pembelajaran pop-up book sedangkan kelas kontrol tidak menggunakan media pembelajaran.

Instrumen dalam penelitian menggunakan lemabar observasi aktivitas guru digunakan untuk mengukur ketercapaian keterlaksanaan pembelajaran, lembar angket untuk mengukur motivasi belajar, dan lembar tes untuk melihat asil belajar peserta didik. Instrumen-instrumen tersebut sebelumnya telah di validasi terlebih dahulu. Menurut Sugiyono (2018:173) Valid berarti instrumen tersebut dapat digunakan untuk mengukur apa yang seharusnya diukur. Metode pengumpulan data dalam penelitian ini dapat diambil dari angket motivasi belajar dengan bantuan angket yaitu berupa tes awal 
pembelajaran (pre-test) dan tes akhir pembelajaran (post-test) dan hasil belajar peserta didik dengan bantuan tes yaitu berupa tes awal pembelajaran (pre-test) dan tes akhir pembelajaran (post-test). Teknik analisis data dalam penelitian ini menggunakan statistik inferensial. Uji yang digunakan untuk statistik inferensial adalah sebagai berikut: (1) Uji normalitas, (2) Uji homogenitas, (3) Uji hipotesis berupa uji t-test, dan (4) Uji GainScore.

\section{HASIL DAN PEMBAHASAN}

\section{Hasil Penelitian}

Pada tahap awal, peneliti memberikan tes awal (pre-test) dan angket (pre-test) kepada kelas eksperimen dan kelas kontrol dengan tujuan melihat kemampuan awal peserta didik dari masing-masing kelas. Tahap selanjutnya adalah peneliti memberikan perlakuan (treatment) berupa penggunaan media pembelajaran Pop-Up Book pada kelas eksperimen sebanyak dua kali pertemuan. Sedangkan pada kelas kontrol peneliti tidak menggunakan media pembelajaran yang dilakukan sebanyak dua kali pertemuan.

Pada tahap akhir setelah pemberian perlakuan (treatment), peneliti memberikan tes akhir (post-test) dan angket (post-test) kepada kelas eksperimen dan kelas kontrol dengan tujuan untuk melihat perbandingan hasil belajar antara kelas eksperimen dengan kelas kontrol. Pada tahap kegiatan pelaksanaan penelitian, peneliti menggunakan lembar observasi aktifitas guru dengan tujuan untuk mengukur ketercapaian penggunaan media pembelajaran pop-up book yang telah dilaksanakan peneliti saat proses pembelajaran dilaksanakan.

Berdasarkan

lembar

keterlaksanaan pembelajaran yang diisi oleh observer, skor total yang diperoleh yakni $100 \%$. Sehingga persentase keterlaksanaan pembelajaran menggunakan media pembelajaran pop-up book terlaksana sangat baik. Hal ini dapat dilihat dari skor yang dicapai oleh peserta didik kelas eksperimen pada pertemuan pertama memperoleh skor sebesar $80 \%$ dengan kategori baik. Selanjutnya pada pertemuan kedua selama proses pembelajaran mendapatkan skor sebesar 95\% kategori sangat baik.

Tabel 1. Hasil Observasi Aktifitas Mengajar Guru

\begin{tabular}{|c|c|c|}
\hline \multirow{2}{*}{ Kelas } & \multicolumn{2}{|c|}{$\begin{array}{c}\text { Presentase Aktifitas Guru } \\
\text { Kategori }\end{array}$} \\
\hline \multirow{2}{*}{ Eksperimen } & Pertemuan I & $80 \%$ (Baik) \\
\cline { 2 - 3 } & Pertemuan II & $95 \%$ (Sangat Baik) \\
\hline
\end{tabular}

Data penelitian ini adalah data kemampuan awal peserta didik. Data yang digunakan adalah data hasil pre-test. Pada pelaksanaan penelitian data kemampuan awal peserta didik dapat ditunjukan pada tabel 2

Tabel 2. Data Nilai Pre-Test Motivasi Belajar Kelas Eksperimen dan Kontrol

\begin{tabular}{cccccc}
\hline Kelas & Jumlah Data & $\begin{array}{c}\text { Nilai } \\
\text { Tertinggi }\end{array}$ & $\begin{array}{c}\text { Nilai } \\
\text { Terendah }\end{array}$ & Rata-rata & $\begin{array}{c}\text { Standar } \\
\text { Deviasi }\end{array}$ \\
\hline Eksperimen & 15 & 70 & 45 & 57.2 & 8.478544349 \\
\hline Kontrol & 15 & 72 & 47 & 59.2 & 9.009518776 \\
\hline
\end{tabular}

Data penelitian ini adalah data kemampuan akhir peserta didik. Data yang digunakan adalah data hasil post-test. Pada pelaksanaan penelitian data kemampuan akhir peserta didik dapat ditunjukan pada tabel 3.

Tabel 3 Data Nilai Post-Test Motivasi Belajar Kelas Eksperimen dan Kontrol

\begin{tabular}{cccccc}
\hline Kelas & $\begin{array}{c}\text { Jumlah } \\
\text { Data }\end{array}$ & $\begin{array}{c}\text { Nilai } \\
\text { Tertinggi }\end{array}$ & $\begin{array}{c}\text { Nilai } \\
\text { Terendah }\end{array}$ & Rata-rata & $\begin{array}{c}\text { Standar } \\
\text { Deviasi }\end{array}$ \\
\hline Eksperimen & 15 & 79 & 57 & 74.46666667 & 6.197541755 \\
\hline Kontrol & 15 & 75 & 55 & 67.13333333 & 6.197541755 \\
\hline & & & & &
\end{tabular}

Berdasarkan tabel 2 dan 3 yang disajikan di atas, dapat kita lihat hasil pretest dan post-test motivasi belajar peserta didik kelas V SDN 3 KAWO. Jumlah peserta didik kelas eksperimen 15 peserta didik dan jumlah peserta didik kelas kontrol 15 peserta didik. Hasil pre-test motivasi belajar kelas eksperimen rata-rata 57.2 dan rata-rata kelas kontrol 59.2. Dari data diatas, terlihat bahwa motivasi belajar kelas eksperimen memperoleh nilai tertinggi 70 dan nilai terendah 45 . Sedangkan pada saat post-test kelas eksperimen rata-rata 74.46 dengan nilai tertinggi 79 dan terendah 57. Sementara itu kelas kontrol mendapat nilai rata-rata 67.13 dengan nilai tertinggi 75 dan nilai terendah 55 . 


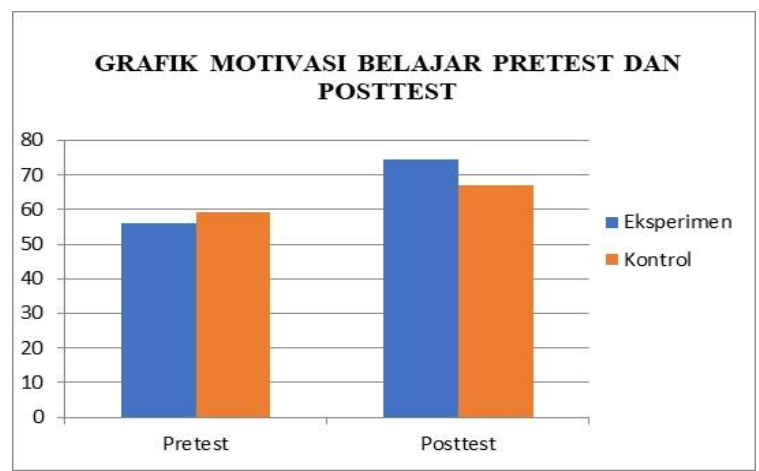

Gambar 1 Grafik Perbandingan Pre-test dan Post-test Motivasi Belajar Kelas Eksperimen dan Kontrol

Berdasarkan gambar grafik di atas diketahui rata-rata nilai motivasi belajar peserta didik pada saat pre-test kelas eksperimen 57.2 dan nilai rata-rata motivasi belajar peserta didik kelas kontrol 59.2. Setelah diberikan perlakuan menggunakan media pembelajaran pop-up book hasil post-testkelas eksperimen memiliki nilai rata-rata 74.46 . Sedangkan kelas kontrol yang menggunakan media pembelajaran konvesional memiliki nilai rata-rata 67.13. Hal ini menunjukan bahwa nilai motivasi belajar kelas eksperimen yang menggunakan media pembelajaran pop-up book ada perubahan dibandingkan dengan kelas kontrol yang hanya menggunakan model pembelajaran konvesional.

Data penelitian ini adalah data kemampuan awal peserta didik. Data yang digunakan adalah data hasil pre-test. Pada pelaksanaan penelitian data kemampuan awal peserta didik dapat ditunjukan pada tabel 4.

Tabel 4 Data Nilai Pre-Test Hasil Belajar Kelas Eksperimen dan Kontrol

\begin{tabular}{cccccc}
\hline Kelas & $\begin{array}{c}\text { Jumlah } \\
\text { Data }\end{array}$ & $\begin{array}{c}\text { Nilai } \\
\text { Tertinggi }\end{array}$ & $\begin{array}{c}\text { Nilai } \\
\text { Terendah }\end{array}$ & $\begin{array}{c}\text { Rata- } \\
\text { rata }\end{array}$ & $\begin{array}{c}\text { Standar } \\
\text { Deviasi }\end{array}$ \\
\hline Eksperimen & 15 & 65 & 35 & 52 & 8.618916074 \\
\hline Kontrol & 15 & 70 & 40 & 52.33 & 9.976162064 \\
\hline
\end{tabular}

Data penelitian ini adalah data kemampuan akhir peserta didik. Data yang digunakan adalah data hasil post-test. Pada pelaksanaan penelitian data kemampuan akhir peserta didik dapat ditunjukan pada tabel 5.

Tebel 5 Data Nilai Post-Test Hasil Belajar Kelas Eksperimen dan Kontrol

\begin{tabular}{cccccc}
\hline Kelas & $\begin{array}{c}\text { Jumlah } \\
\text { Data }\end{array}$ & $\begin{array}{c}\text { Nilai } \\
\text { Tertinggi }\end{array}$ & $\begin{array}{c}\text { Nilai } \\
\text { Terendah }\end{array}$ & $\begin{array}{c}\text { Rata- } \\
\text { rata }\end{array}$ & $\begin{array}{c}\text { Standar } \\
\text { Deviasi }\end{array}$ \\
\hline Eksperimen & 15 & 95 & 60 & 79.67 & 11.2546287 \\
\hline Kontrol & 15 & 90 & 55 & 71 & 10.21203771 \\
\hline
\end{tabular}

Berdasarkan tabel 4 dan 5 yang disajikan di atas, dapat kita lihat hasil pretest dan post-test peserta didik kelas $\mathrm{V}$ SDN 3 KAWO. Jumlah peserta didik kelas eksperimen 15 peserta didik dan jumlah peserta didik kelas kontrol 15 peserta didik. Hasil pre-test kelas eksperimen ratarata 52 dan rata-rata kelas kontrol 52.33. Dari data diatas, terlihat bahwa hasil belajar kelas eksperimen memperoleh nilai tertinggi 65 dan nilai terendah 35 yang dimana pada pretest kelas eksperimen hanya 2 peserta didik yang dinyatakan tuntas dengan nilai 65 dan pada kelas kontrol hanya 4 peserta didik yang dinyatakan tuntas dengan nilai 65 dan 70 dan nilai terendah 40 serta peserta didik lain mendapatkan nilai dibawah 65 . Sedangkan pada saat post-test kelas eksperimen rata-rata 79.67 dengan nilai tertinggi 95 dan terendah 60 dimana peserta didik yang mendapat kriteria tuntas sejumlah 13 peserta didik yang mendapat nilai di atas 65 keatas dan 2 peserta didik belum tuntas dengan nilai dibawah 65 . Sementara itu kelas kontrol mendapat nilai rata-rata 71 dengan nilai tertinggi 90 dan nilai terendah 55. Pada kelas kontrol ada 5 peserta didik yang belum tuntas dengan nilai 65 kebawah sedangkan 10 peserta didik lainnya mendapat nilai ketuntasan dengan nilai 65 keatas.

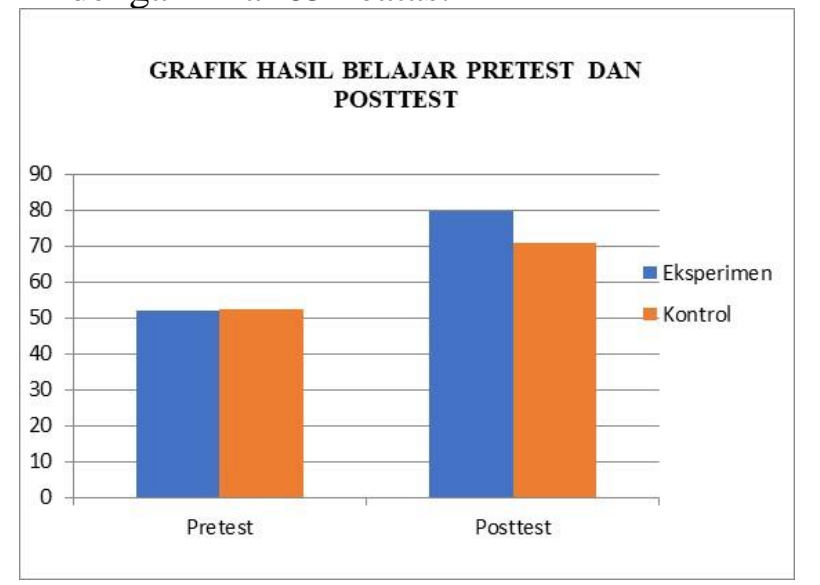

\section{Gambar 2 Grafik Perbandingan Pre-test dan Post-test Hasil Belajar Kelas Eksperimen dan Kontrol}

Berdasarkan gambar grafik di atas diketahui rata-rata nilai hasil belajar peserta didik pada saat pre-test kelas eksperimen 52 dan hasil belajar peserta 
didik kelas kontrol 52.33. Setelah diberikan perlakuan menggunakan media pembelajaran pop-up book hasil post-test kelas eksperimen memiliki nilai rata-rata 79.67. Sedangkan kelas kontrol yang menggunakan media pembelajaran konvesional memiliki nilai rata-rata 71 . Hal ini menunjukan bahwa nilai hasil belajar kelas eksperimen yang menggunakan media pembelajaran pop-up book ada perubahan dibandingkan dengan kelas kontrol yang hanya menggunakan model pembelajaran konvesional.

Analisis data bertujuan untuk mengetahui hasil penelitian mengenai pengaruh penerapan media pembelajaran pop-up book terhadap motivasi dan hasil belajar IPA peserta didik kelas V. Untuk mengetahjui adanya pengaruh yang signifikan atau tidak, maka perlu dilakukan uji hipotesis menggunakan uji $\mathrm{T}$ test (uji t). sebelum melakukan mengujian terhadap hipotesis, maka perlu dilakukan uji prsayarat terlebih dahulu. Adapun uji prasayarat dalam penelitian ini adalah sebagai berikut:

Setelah data hasil motivasi belajar IPA didapatkan. Langkah selanjutnya adalah melakukan uji normalitas data. Tujuan dilakukannya uji normalitas adalah untuk mengetahui data berdistribusi normal atau tidak. Uji normalitas data menggunakan Kolmogorov Smirnov dengan bantuan program SPSS 21.0 for windows. Data dinyatakan normal jika nilai signifikam lebih besar dari $5 \%$ atau 0,05 . Pengujian normalitas untuk motivasi belajar IPA peserta didik menggunakan bantuan SPSS 21.0 for windows dapat dilihat pada tabel 6 .

Tabel 6 Uji Normalitas Data Motivasi Belajar Kelas Eksperimen dan Kontrol

\begin{tabular}{|c|c|c|c|c|c|c|}
\hline & \multicolumn{3}{|c|}{ Kolmogorov-Smirnov } & \multicolumn{3}{|c|}{ Shapiro-Wilk } \\
\hline & Statistic & df & Sig. & Statistic & df & Sig. \\
\hline Pretest_Eksperimen & .167 & 15 & $.200^{\circ}$ & .907 & 15 & .122 \\
\hline Pretest_Kontrol & .155 & 15 & $.200^{*}$ & .900 & 15 & .094 \\
\hline Posttest_Eksperimen & .186 & 15 & .172 & .838 & 15 & .012 \\
\hline Posttest_Kontrol & .105 & 15 & $.200^{*}$ & .971 & 15 & .871 \\
\hline
\end{tabular}

Berdasarkan tabel 6 perhitungan uji normalitas data menggunakan bantuan aplikasi SPSS 21.0 for windows diketahui bahwa nilai signifikansi data sebesar .200 dan .200 untuk pre-test sedangkan untuk post-test nilai signifikannya sebesar .172 dan .200. Jika dibandingkan dengan taraf signifikan 0,05. Nilai signifikan uji normalitas keduanya baik eksperimen maupun kontrol lebih besar dari 0,05 maka dapat disimpulkan bahwa data penelitian berdistribusi normal.

Setelah data hasil belajar IPA didapatkan. Langkah selanjutnya adalah melakukan uji normalitas data. Tujuan dilakukannya uji normalitas adalah untuk mengetahui data berdistribusi normal atau tidak. Uji normalitas data menggunakan Kolmogorov Smirnov dengan bantuan program SPSS 21.0 fot windows. Data dinyatakan normal jika nilai signifikam lebih besar dari 5\% atau o,o5. Pengujian normalitas untuk hasil belajar IPA peserta didik menggunakan bantuan SPSS 21.0 fot windowsdapat dilihat pada tabel 7.

Tabel 7 Uji Normalitas Data Hasil Belajar Kelas Eksperimen dan Kontrol

\begin{tabular}{|c|c|c|c|c|c|c|}
\hline \multicolumn{7}{|c|}{ Tests of Normality } \\
\hline & \multicolumn{3}{|c|}{ Kolmogorov-Smirnova } & \multicolumn{3}{|c|}{ Shapiro-Wilk } \\
\hline & Statistic & df & Sig. & Statistic & df & Sig. \\
\hline Pretest_Eksperimen & .208 & 15 & .079 & .923 & 15 & .211 \\
\hline Pretest_Kontrol & .192 & 15 & .140 & .904 & 15 & .111 \\
\hline Posttest_Eksperimen & .216 & 15 & .059 & .910 & 15 & .134 \\
\hline Posttest_Kontrol & 193 & 15 & .139 & .901 & 15 & .098 \\
\hline
\end{tabular}

Berdasarkan tabel 7 perhitungan uji normalitas data menggunakan bantuan aplikasi SPSS 21.0 for windows diketahui bahwa nilai signifikansi data sebesar .079 dan .140 untuk pre-test sedangkan untuk post-test nilai signifikannya sebesar .059 dan .139. Jika di interpretasikan maka nilai tersebut menjadi 0,079 dan 0,140 untuk pre-test dan 0,059 dan 0,139 untuk posttest. Jika dibandingkan dengan taraf signifikan 0,05. Nilai signifikan uji normalitas keduanya baik eksperimen maupun kontrol lebih besar dari 0,05 maka dapat disimpulkan bahwa data penelitian berdistribusi normal.

Uji komogenitas bertujuan untuk mengatahui apakah objek yang diteliti mempunyai varian homogen atau tidak. Uji homogenitas varians terbesar dan varians terkecil dengan menggunkaan selisih nilai post-test dan pre-test kedua kelas digunakan untuk mengatahui tindak lanjut uji hipotesisi (t-test) yang akan digunakan, 
berikut hasil uji homogenitas menggunakan uji Levene Statistic dengan bantuan aplikasi SPSS 21.0 for windows yang disajikan dalam bentuk tabel 8 .

Tabel 8 Uji Homogenitas Motivasi Belajar Kelas Eksperimen dan Kontrol Test of Homogeneity of Variances

\begin{tabular}{|l|r|r|r|r|}
\hline & \multicolumn{1}{|c|}{$\begin{array}{l}\text { Levene } \\
\text { Statistic }\end{array}$} & \multicolumn{1}{c|}{$\mathrm{df1}$} & \multicolumn{1}{c|}{$\mathrm{df2}$} & \multicolumn{1}{c|}{ Sig. } \\
\hline Nilai_Pretest & .282 & 1 & 28 & .599 \\
Nilai_Posttest & .044 & 1 & 28 & .836 \\
\hline
\end{tabular}

Berdasarkan tabel 8 diketahui nilai signifikansi (sig) pada pre-test adalah sebesar 0,599 dan post-test sebesar 0,836 > 0,05 , sehingga dapat disimpulkan bahwa varian pre-test dan post-test adalah sama atau varian sampel penelitian ini dikatakan homogen.

Uji komogenitas bertujuan untuk mengatahui apakah objek yang diteliti mempunyai varian homogen atau tidak. Uji homogenitas varians terbesar dan varians terkecil dengan menggunkaan selisih nilai post-test dan pre-test kedua kelas digunakan untuk mengatahui tindak lanjut uji hipotesisi (t-test) yang akan digunakan, berikut hasil uji homogenitas menggunakan uji Levene Statistic dengan bantuan aplikasi SPSS 21.0 for windows yang disajikan dalam bentuk tabel 9

Tabel 9 Uji Homogenitas Hasil Belajar Kelas Eksperimen dan Kontrol

Test of Homogeneity of Variances

\begin{tabular}{|l|r|r|r|l|}
\hline & \multicolumn{1}{|l|}{$\begin{array}{l}\text { Levene } \\
\text { Statistic }\end{array}$} & \multicolumn{1}{c|}{$\mathrm{df1}$} & \multicolumn{1}{c|}{$\mathrm{df2}$} & \multicolumn{1}{c|}{ Sig. } \\
\hline Nilai_Pretest & .671 & 1 & 28 & .420 \\
Nilai_Posttest & .005 & 1 & 28 & .946 \\
\hline
\end{tabular}

Berdasarkan tabel 9 diketahui nilai signifikansi (sig) pada pre-test adalah sebesar 0,420 dan post-test sebesar 0,946 > 0,05 , sehingga dapat disimpulkan bahwa varian pre-test dan post-test adalah sama atau varian sampel penelitian ini dikatakan homogeny.

Uji hopotesis dilakukan setelah uji normalitas data dan uji homogenitas. Adapun uji hoptesis ini dilakukan karena kedua persyaratan telah terpenuhi pada kedua kelas tersebut yaitu dara berdistribusi normal dan data berdifat homogen. Oleh karena itu, uji hipotesis ini dapat dilakukan dengan menggunakan uji-t yang bertujuan untuk mengetahui apakah ada pengaruh penerapan media pembelajaran pop-up book terhadap motivasi dan hasil belajar IPA peserta didik kelas V SDN 3 KAWO tahun ajaran 2020/2021. Adapun uji hipotesis dalam penelitian ini mengunakan Uji-t sampel independent atau Independent Sample Ttest dihitung dengan bantuan program analisis statistic SPSS 21.0 For Windows dengan taraf signifikansi 5\% atau 0,05. Ketentuan pengujian hipotesis ini ialah, jika taraf signifikansi <0,05, maka hipotesis alternatif (Ha) diterima sedangkan Hipotesis nol $\left(\mathrm{H}_{0}\right)$ ditolak, sebaliknya jika taraf signifikansi > 0,05, maka hipotesis alternatif (Ha) ditolak sedangkan hipotesis nol $\left(\mathrm{H}_{0}\right)$ diterima. Adapun hasil uji hipotesis yang diperoleh dengan menggunakan Independent Sample T-test dapat dilihat pada tabel berikut:

Tabel 10 Hasil Uji Hipotesis Data Posttest Motivasi Belajar IPA

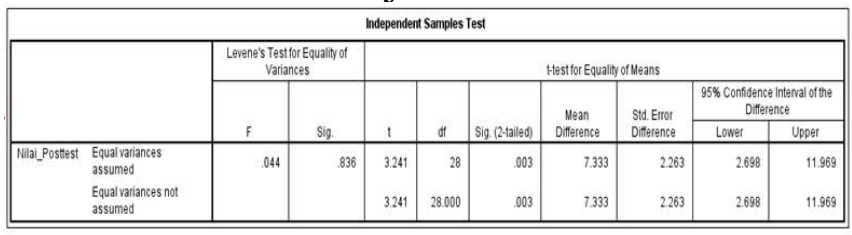

Berdasarkan tabel diatas, dapat diketahui nilai thitung sebesar 3.241, dengan derajat kebebasan $(\mathrm{df})=15+15$ $2=28$, didapatkan hasil t-tabel sebesar 2.048. dengan ini, dapat disimpulkan bahwa t-hitung (3.241) > ttabel (2.048) artinya, Ho ditolak dan $\mathrm{Ha}$ diterima. Hal ini menunjukkan bahwa ada pengaruh penerapan media pembelajaran pop-up book terhadap motivasi belajar IPA peserta didik kelas V SDN 3 KAWO tahun ajaran 2020/2021.

Tabel 11 Hasil Uji Hipotesis Data Posttest Hasil Belajar IPA

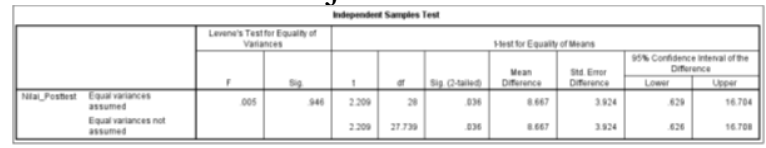

Berdasarkan tabel diatas, dapat diketahui nilai t-hitung sebesar 2.209, dengan derajat kebebasan $(\mathrm{df})=$ $15+15-2=28$, didapatkan hasil t-tabel sebesar 2.048. dengan ini, dapat disimpulkan bahwa t-hitung (2.209) > t-tabel (2.048) artinya, Ho ditolak dan 
Ha diterima. Hal ini menunjukkan bahwa ada pengaruh penerapan media pembelajaran pop-up book terhadap hasil belajar IPA peserta didik kelas V SDN 3 KAWO tahun ajaran 2020/2021.

Untuk mengetahui seberapa besar pengaruh penerapan media pembalajarn pop-up book terhadap motivasi dan hasil belajar IPA peserta didik kelas V SDN 3 KAWO tahun ajaran 2020/2021 diuji dengan menggunakan analisis gain score, hasilnya dapat dilihat pada perhitungan di bawah ini:

1. Hasil perhitungan motivasi belajar

$$
\begin{gathered}
<\mathrm{g}>=\frac{\text { posttest }- \text { pretst }}{100-\text { pretest }} \\
<\mathrm{g}>=\frac{74,47-57,2}{100-57,2} \\
<\mathrm{g}>=0,403
\end{gathered}
$$

2. Hasil perhitungan hasil belajar

$$
\begin{gathered}
<\mathrm{g}>=\frac{\text { posttest }- \text { pretst }}{100-\text { pretest }} \\
<\mathrm{g}>=\frac{79,67-52}{100-52} \\
<\mathrm{g}>=0,576
\end{gathered}
$$

Dari perhitungan gain score di ats didapatkan hasil motivasi belajar sebesar 0,403 termasuk dalam kategori sedang, sedangkan gain score hasil belajar sebesar 0,576 termasuk dalam kategori sedang.

\section{Pembahasan}

Penelitian ini bertujuan untuk mengetahui apakah ada pengaruh penerapan media pembelajaran pop-up book terhadap motivasi dan hasil belajar IPA peserta didik kelas V SDN 3 KAWO tahun ajaran 2020/2021. Pada penelitian ini terdapat tiga variabel yaitu motivasi dan hasil belajar sebagai variabel bebas (variabel independen) dan variabel terikat (variabel dependen) yaitu media pembelajaran pop-up book.

Penelitian ini diawali dengan pemberian pretest pada kelas eksperimen dan kelas kontrol dengan tujuan untuk melihat kemampuan awal peserta didik. Rata-rata nilai pretest kelas eksperimen motivasi belajar sebesar 57.2 sedangkan untuk kelas kontrol motivasi belajar sebesar 59.2. Rata-rata nilai pretest kelas ekperimen hasil belajar sebesar 52, sedangkan untuk kelas kontrol hasil belajar sebesar 52.33. Hasil ini menunjukkan bahwa kedua kelas memiliki kemampuan awal yang relatif sama, sehingga dapat dilanjutkan untuk pemberian perlakuan. Selanjutnya peneliti memberikan perlakuan dengan menerapkan media pembelajaran popup book pada pelajaran IPA di kelas eksperimen sebanyak dua kali pertemuan dan melakukan kegiatan pembelajaran dengan menerapkan pembelajaran konvensional pada kelas kontrol sebanyak dua kali pertemuan.

Berdasarkan nilai posttest yang diperoleh kelas eksperimen dan kelas kontrol dapat diketahui bahwa nilai rata-rata kedua kelas mengalami peningkatan dengan nilai rata-rata dari kelas eksperimen lebih tinggi dibandingkan dengan kelas kontrol. Selanjutkan dilakukan uji prasayarat untuk membuktikan hipotesis yang telah dibuat sebelumnya. Uji prasyarat yang dilakukan pertama adalah uji normalitas, kemudian uji homogenitas dan yang terakhir dilakukan uji hipotesis. Pada uji normalitas menggunakan rumus kologorov-Smirnov berbantuan SPSS 21.0 for windows didapatkan hasil pengujian normalitas data dengan kriteria pengambilan keputusan yaitu taraf signifikansi $>0.05$, maka data berdistribusi normal.

Uji normalitas ini dilakukan pada data kedua kelas yaitu kelas eksperimen dan kelas kontrol yang meliputi hasil tes awal (pretest) dan hasil tes akhir (posttest) masing-masing kelompok. Berdasarkan data yang diperoleh pada tabel 4.6 dan 4.7 dapat dilihat bahwa hasil menginterpretasikan sebaran data pretest dan posttest di kelas eksperimen dan kelas kontrol beristribusi normal. Terlihat nilai signifikansi data motivasi belajar sebesar sebesar 0.200 dan 0.200 untuk pretest sedangkan untuk posttest 0.172 dan 0.200 . pada nilai signifikansi data hasil belajar sebesar 0.079 dan 0.140 untuk pretest sedangkan untuk posttest nilai signifikannya sebesar 0.059 dan 0.139. Jika dibandingkan dengan taraf signifikan 0.05 nilai signifikan uji normalitas keduanya baik eksperimen maupun kontrol lebih besar dari 0.05 maka dapat disimpulkan bahwa data penelitian 
berdistribusi normal. Data tersebut menerangkan bahwa syarat pengujian hipotesis telah terpenuhi. Pada pengujian homogenitas menggunakan data hasil posttest, didapatkan hasil bahwa kelas kontrol dan kelas eksperimen adalah homogen. Nilai yang didapatkan dapat dilihat pada tabel 4.8 dan 4.9 bahwa nilai signifikansi motivasi belajar sebesar $0.836>0.005$, sedangkan nilai signifikansi hasil belajar sebesar $0.946>0.05$, sehingga dapat disimpulkan bahwa varian data motivasi dan hasil posttest kelas eksperimen dan kelas kontrol adalah sama atau homogen.

Setelah dilakukan uji normalitas dan homogenitas, maka selanjutkan dilakukan uji hipotesis. Berdasarkan perhitungan uji hipotesis menggunakan rumus independent samples test dibantu oleh aplikasi statistik SPSS 21.0 for windows. Media pembelajaran pop-up book dikatakan berpengaruh, jika hasil t-hitung > t-tabel hasil perhitungan uji hipotesis diperoleh t-hitung sebesar 3.241 sedangkan t-tabel pada taraf signifikansi 5\% adalah sebesar 2.048 sehingga diperoleh nilai t-hitung > t-tabel, yang berarti bahwa Ha, yang menyatakan ada pengaruh penerapan media pembelajaran pop-up book terhadap motivasi belajar IPA peserta didik kelas V SDN 3 KAWO tahun ajaran 2020/2021, diterima dan yang menyatakan tidak ada pengaruh penerapan media pembelajaran popup book terhadap motivasi belajar IPA peserta didik kelas V SDN 3 KAWO tahun ajaran 2020/2021, ditolak. Dan diperoleh t-hitung sebesar 2.209 sedangkan t-tabel pada taraf signifikansi $5 \%$ adalah sebesar 2.048 sehingga diperoleh nilai t-hitung > t-tabel, yang berarti bahwa Ha, yang menyatakan ada pengaruh penerapan media pembelajaran popup book terhadap hasil belajar IPA peserta didik kelas V SDN 3 KAWO tahun ajaran 2020/2021, diterima dan yang menyatakan tidak ada pengaruh penerapan media pembelajaran pop-up book terhadap hasil belajar IPA peserta didik kelas V SDN 3 KAWO tahun ajaran 2020/2021, ditolak.

Setelah melakukan uji hipotesis maka peneliti melakukan sebuah uji lanjutan dengan menggunakan uji rumus gain score yang bertujuan untuk mengetahui seberapa besar pengaruh penerapan media pembelajaran popup book terhadap motivasi dan hasil belajar peserta didik kelas V SDN 3 KAWO tahun pelajaran 2020/2021. Dari perhitungan gain score di atas didapatkan hasil motivasi belajar sebesar 0,403 termasuk dalam kategori sedang, sedangkan gain score hasil belajar sebesar 0,576 termasuk dalam kategori sedang.

\section{KESIMPULAN}

Berdasarkan perhitungan uji hipotesis menggunakan rumus indepenedent samples test dibantu oleh aplikasi statistik SPSS 21.0 for windows. Media pembelajaran pop-up book dikatakan berpengaruh, jika hasil thitung > t-tabel hasil perhitungan uji hipotesis diperoleh t-hitung sebesar 3.241 sedangkan ttabel pada taraf signifikansi $5 \%$ adalah sebesar 2.048 sehingga diperoleh nilai thitung > t-tabel, yang berarti bahwa Ha, yang menyatakan ada pengaruh penerapan media pembelajaran pop-up book terhadap motivasi belajar IPA peserta didik kelas V SDN 3 KAWO tahun ajaran 2020/2021, diterima dan $\mathrm{H}_{0}$ yang menyatakan tidak ada pengaruh penerapan media pembelajaran pop-up book terhadap motivasi belajar IPA peserta didik kelas V SDN 3 KAWO tahun ajaran 2020/2021, ditolak. Dan diperoleh t-hitung sebesar 2.209 sedangkan t-tabel pada taraf signifikansi $5 \%$ adalah sebesar 2.048 sehingga diperoleh nilai t-hitung > t-tabel, yang berarti bahwa Ha, yang menyatakan ada pengaruh penerapan media pembelajaran popup book terhadap hasil belajar IPA peserta didik kelas V SDN 3 KAWO tahun ajaran 2020/2021, diterima dan $\mathrm{H}_{0}$ yang menyatakan tidak ada pengaruh penerapan media pembelajaran pop-up book terhadap hasil belajar IPA peserta didik kelas V SDN 3 KAWO tahun ajaran 2020/2021, ditolak.

Setelah melakukan uji hipotesis maka peneliti melakukan sebuah uji lanjutan dengan menggunakan uji rumus gain score yang bertujuan untuk mengetahui seberapa besar pengaruh penerapan media pembelajaran popup book terhadap motivasi dan hasil belajar peserta didik kelas V SDN 3 KAWO tahun pelajaran 2020/2021. Dari perhitungan gain score di atas didapatkan hasil motivasi belajar 
sebesar 0,403 termasuk dalam kategori sedang, sedangkan gain score hasil belajar sebesar 0,576 termasuk dalam kategori sedang.

\section{Saran}

Berdasarkan kesimpulan di atas dan
hasil pengamatan pada saat proses pembelajaran yang terjadi pada proses penelitian, maka saran yang dapat diberikan adalah sebagai berikut:

\section{Saran untuk Sekolah}

Dengan hasil penelitian yang telah saya lakukan diharapkan sekolah mendukung dan mengajak serta memfasilitasi guru untuk menggunakan media pembelajaran setiap mengajar, agar pembelajaran dapat berlangsung dengan menarik dan dapat meningkatkan semangat serta motivasi peserta didik dalam proses pembelajaran.

2. Saran untuk Guru

Dengan hasil penelitian ini dalam proses pembelajaran menggunakan media pembelaran pop-up book dapat dijadikan suatu referensi dalam mengajar khususnya pada pembelajaran IPA, agar pembelajaran dapat menarik dan peserta didik semangat karena memiliki motivasi dalam belajar.

3. Saran untuk Peserta Didik

Dengan hasil penelitian ini peserta didik diharapkan dapat belajar dengan cara yang berbeda dan menarik yang berkaitan dengan kehidupan nyata agar terciptanya proses pembelajaran yang efektif.

4. Saran untuk Peneliti Lain

Bagi peneliti selanjutnya, peneliti ini bukan hanya dijadikan sebagai referensi dalam melakukan penelitian, namun diharapkan dilakukan dengan materi yang berbeda dan tempat yang berbeda dan diharapkan dapat dikembangkan lagi menjadi lebih sempurna.

\section{DAFTAR PUSTAKA}

Arikunto. 2013. prosedur penelitian suatu pendekatan praktik. Jakarta: rineka cipta.

Arsyad, Azhar. 2014. Me-dia Pembelajaran. Jakarta: PT Raja Grafindo Persada

Cepi Riyana. 2017. Media Pembelajaran. Bandung: CV WACANA PRIMA

Indah Sylvia, Nur., \& Sri Hariani. 2015.
Pengaruh Penggunaan Media PopUp Book Terhadap Keterampilan Menulis Narasi Siswa Sekolah dasar, "JPGSD. (Vol. 3 Nomor 2)

Jatu, P. 2015. Pengembangan Media Pop-Up Book Tema Peristiwa untuk Kelas III SD Negeri Pakem I. Jurnal Universitas Negeri Yogyakarta. 4(8):22-24

Kustandi, Cecep. 2020. Pengembangan Media pembelajaran. Jakarta. KENCANA

Mulianti, Eli Sri. 2017. Pengembangan media pembelajaran Pop-Up Book pembelajaran matematika kelas II MI Ma'arif BEGO Maguwoharjo sleman Yogyakarta

Musfiqon. 2012. Pengembangan Media dan Sumber Pembelajaran. Jakarta: Prestasi Pustaka Publisher

Mustofa, R., \& Syafi'ah, ar. (2018). Pengembangan Media Pembelajaran Pop-Up Book Mteri Pokok Kenampakan Permukaan Bumi pada Mata Pelajaran IPA Kelas III SDN 1 Banaran Kecamatan Kauman Kabupaten Tulunggung. ELSE (Elementary School Education Journal): Jurnal Pendidikan dan Pembelajaran Sekolah Dasar, 2(2). Retriefed From http://journal.umsurabaya.ac.id/index.php/pgsd/articel /view/1723

Nila, R. 2014. Pengaruh Media Pop-Up Book Terhadap Penguasaan Kosakata Anak Usia 5-6 Tahun Di TK Putera Harapan Surabaya. Jurnal Universitas Negeri Surabaya. 4-5

Nurhandayani, 2020. Pengaruh Pendekatan Matematika Realistik Terhadap Motivasi Dan Hasil Belajar Matematika Siswa Kelas IV SDN Gugus II Kecamatan Madapangga Tahun Ajaran 2020/2021

Pramita, Olga., Dkk. 2020. "Pengaruh Penggunaan Media Pop-Up Terhadap Minat dan Hasil Belajar IPA Siswa Kelas IV SD Singosaren".Vol. 6, Nomor 3, mei 2020, hlm. 936-946. https://journal.ustjogja.ac.id/index.ph 
p/trihayu/article diakses tanggal 23 November 2020

Purwanto. 2011. Evaluasi Hasil Belajar. Yogyakarta: Pustaka Belajar

Puspitasari, Ariati Dins. 2015. Efektivitas Pembelajaran Berbasis Guided Inquiry Untuk Meningkatkan Sains Siswa. Jurnal, Pendidikan Fisika, FKIP, Universitas Ahmad Dahlan, Yogyakarta. Vol. 1 (2):1-5

Sardiman, 2012. Interaksi \& Motivasi Belajar Mengajar. Jakarta: PT Rajagrafindo Persada

Sari, Eka Yuliana. 2019. "Pengaruh Penggunaan Media Pembelajaran Buku Poip-Up Terhadap Hasil Belajar Siswa Kelas IV SDN 2 Bendungan Kecamatan Gendong Kabupaten Tulungagung". Volume III. Nomor 2, November 2019. https://journal.unesa.ac.id/index.php/ jpd/articel/view/6511\&ved $=$ Diakses tanggal 23 November 2020

Sholiha, Mariatus., dkk. 2017. "Pengembangan Media Kotak Cahaya Pelajaran IPA Mteri Sifatsifat Cahaya", Jurnal Ilmiah Rekayasa, (Vol. 10 Nomor 1). Hlm. 35

Slameto. 2015. Belajar dan faktor-faktor yang mempengaruhinya. Jakarta: Rineka Cipta

Sudjana, Nana. 2017. Penilaian Hasil Proses Belajar Mengaajar. Bandung : PT. Remaja Rosdakarya

Sugiyono. (2018) Metode Penelitian Pendidikan pendekatan Kuantitatif, Kualitatif dan $R \& D$. Bandung : Alfabeta

Susanto, Ahmad. 2013. Teori Belajar \& Pembelajaran di Sekolah Dasar. Jakarta: Prenadamedia Group

Susanto, Ahmad. 2016. Teori Belajar Dan Pembelajaran di Sekolah Dasar. Jakarta: Prenadamedia Group

Uno, 2011. Teori Motivasi \& Pengukurannya. Jakarta: PT Bumi Aksara 